


\title{
GENETIC IMPROVEMENT OF WEANING WEIGHT, YEARLING WEIGHT, BODY WEIGHT GAIN AND BODY DIMENSION OF BALI CATTLE
}

\author{
A. Supriyantono 1 , L. Hakim ${ }^{2}$, Suyadi2 and Ismudiono $^{3}$ \\ IFaculty of Animal Science, Fishery and Marine Science, The State of Papua University, \\ Jl. Gunung Salju, Amban, Manokwari 98314, West Papua - Indonesia \\ ${ }^{2}$ Faculty of Animal Science, Brawijaya University, Jl. Veteran, Malang 65145, East Java - Indonesia \\ ${ }^{3}$ Faculty of Veterinary Medicine, Airlangga University, \\ Kampus C Unair, Jl. Mulyorejo, Surabaya 60115, East Java - Indonesia \\ Corresponding E-mail: andoyo@yahoo.com \\ Received November 15, 2011; Accepted February 08, 2012
}

\begin{abstract}
ABSTRAK
Tujuan penelitian ini adalah untuk mengevaluasi peningkatan genetik sifat-sifat produksi pada sapi Bali. Sebanyak 428 data bobot sapih, bobot setahun dan pertambahan bobot badan digunakan untuk menduga peningkatan genetik sifat-sifat tersebut. Seratus tujuh data ukuran tubuh (bobot badan, lingkar dada, panjang badan dan tinggi gumba) pada umur 24 bulan juga digunakan untuk menduga peningkatan genetiknya. Pendugaan komponen ragam dan peragam genetik, dan heritabilitas diperoleh dengan menggunakan animal model. Pengaruh tetap untuk bobot sapih, bobot setahun dan pertambahan bobot badan adalah curah hujan, umur pengukuran dan tahun kelahiran, sementara pengaruh tetap untuk ukuran-ukuran tubuh tergantung dari masing-masing karakter. Hasil penelitian menunjukkan bahwa heritabilitas bobot sapih, bobot setahun, pertambahan bobot badan, bobot badan, lingkar dada, panjang badan dan tinggi gumba berturut-turut adalah $0,09 \pm 0,15 ; 0,27 \pm 0,13 ; 0,47 \pm 0,15 ; 0,07 \pm 0,19 ; 0,50 \pm 0,19$; $0,34 \pm 0,28$ dan $0,60 \pm 0,21$. Peningkatan genetik untuk semua karakter mempunyai pola yang berbeda dalam merespon seleksi. Semua karakter tidak menunjukkan peningkatan genetik akibat seleksi.
\end{abstract}

Kata kunci: Sapi Bali, peningkatan genetik, seleksi, karakter produksi

\begin{abstract}
The aim of the research was to evaluate the genetic improving of production traits selected of Bali cattle. Four hundred and twenty eight data of weaning weight, yearling weight and body weight gain were used to estimate genetic improvement for those traits. One hundred and seven data of body dimension (body weight, chest circumference, body length and withers height) at 24 months old were used to estimate genetic improving for those traits. The estimation of genetic and environmental variance and co-variance component, and heritability were found by animal model. The fix effect of weaning weight, yearling weight and body weight gain was rainfall, age of measurement and year of birth, whereas the fix effect of body dimension depend on each trait. The result showed that heritability of weaning weight, yearling weight, body weight gain, body weight, chest circumference, body length and withers height was $0.09 \pm 0.15,0.27 \pm 0.13,0.47 \pm 0.15,0.07 \pm 0.19,0.50 \pm 0.19,0.34 \pm 0.28,0.60 \pm 0.21$, respectively. Genetic improvement of all traits have had a different pattern in selection responses. All traits did not show genetic improvement due to selection for.
\end{abstract}

Keywords: Bali cattle, genetic improvement, selection, production traits

\section{INTRODUCTION}

Growth traits such as birth, weaning and yearling weight are recorded and routinely analyzed in genetic evaluation by beef cattle associations (Kaps et al., 2000). Beef cattle grow to produce meat and other product which utilized by human being. Meat demand in Indonesia increased by $6-8 \%$ each year, especially in densely populated areas such as Java. Based on statistical data of Indonesia in the last five years (2005-2009), the demand of meat increased from 12.393 million tons to 16.24 million tons. Part of meat demand can not be met by Indonesia 
government so that import is one way to cover of the meat shortage. The fulfillment of the meat is partially supplied by local beefs including Bali, Ongole, Madura, and some other breeds. Bali cattle occupies greater number $(26.92 \%)$ than other cattle breeds, it means that the contribution of Bali cattle in meeting the needs of the meat is very significant. However, the performance of Bali cattle in producing meat does not yet meet the maximum requirement. It is still needed some efforts to optimize it.

Attempts to improve the performance of Bali cattle has been done by adopting various feeding strategies (Mastika, 2002), maintenance management (Oka, 2002; Bamualim and Wirdahayati, 2002) and genetic improvement through selection (Graser, 2002; Toelihere, 2002). Selection of Bali cattle in P3Bali (Proyek Pengembangan dan Perbibitan Sapi Bali= Project of Bali Cattle Breeding) has been done to evaluate sires by the progeny test (Sukmasari et al., 2002).

Utilization of breeding value estimation to predict the improvement of production traits was tested by Blair and Pollak (1984) and Sorensen and Kennedy (1984). The estimation of genetic improvement of weaning weight, yearling weight, body weight gain and body conformation of Bali cattle is needed to determine to what extent the genetic improvement of selected traits due to selection has been made. Therefore the objective of the study was to evaluate the genetic improving of production traits selected of Bali cattle.

\section{MATERIALS AND METHODS}

The data consisted of 428 data of weaning weight (WW), yearling weight (YW) and body weight gain (BWG), 107 data body weight (BW), chest circumference (CC), body length (BL) and withers height (WH) of 24 months old originating from P3Bali from 1993 to 2003.

Estimation of components of variance and covariance genetics and environment, and heritability was obtained using VCE 4.2 (Groeneveld, 1998). Fix effect for WW, YW and BWG gain were rainfall, age of measurement and year of birth, whereas the fix effect for $\mathrm{WH}$ : rainfall, age of measurement, parity and age of dam; CC: rainfall, age of measurement and year of birth; $\mathrm{BL}$ and $\mathrm{BW}$ : rainfall, age of measurement, parity, age of dam, season and year of birth. As random effects for all the characters were animals.
In general, statistical models for animal model is as follows: $\mathrm{y}=\mathrm{X} \beta+\mathrm{Zu}+\mathrm{e}$, with $\mathrm{y}$ is the vector of the records for each traits; $\beta$ is the vector of fixed effects; and $\mathrm{u}$ is the vector of random individual additive genetic effects with incidence matrices $\mathrm{X}$ and $\mathrm{Z}$, and $\mathrm{e}$ is the vector of the environment effect.

Estimation of breeding value for each trait was done by using PEST (Groeneveld, 1998) by inserting the genetic (vg) and environmental (ve) variance of the same trait. The variances was obtained from the output of the program VCE 4.2.

\section{RESULTS AND DISCUSSION}

Heritability (h2) of WW, YW, BWG, BW, $\mathrm{CC}, \mathrm{BL}$ and $\mathrm{WH}$ measured at 24 months old are presented in Table 1. The heritability of WW was low (0.09) and unexpected estimation even the standard deviation (0.15) was larger than the heritability. However, other heritabilities were in accordance to most study (Jan, 2000; Sukmasari et al., 2002; Kaps et al., 2000). Jan (2000) and Sukmasari et al. (2002) showed that heritability of weaning weight and yearling weight was $0.44 \pm 0.09$ and $0.23 \pm 0.02$ for weaning weight; $0.10 \pm 0.05$ and $0.38 \pm 0.02$ for yearling weight, respectively. On the Angus breed the heritability of weaning weight is very diverse, ranging from 0.20 to 0.66 (Kaps et al., 2000).

According to MacNeil et al. (2000) the difference in the heritability was due to differences in populations that have a heterogeneous environment thus making differences of the heritability and gene frequency and the differences in methods of analysis that make a difference in the accuracy (Kealey et al., 2006). Animal models used to estimate the heritability could not obtain heritability as we expected which is about 0.30 to 0.55 . Kealey at al. (2006) stated that the low estimation of genetic variance may indicate substantial environmental influences. Other cause of the low heritability is the least amount of data of weaning weight that is about 428 data. These results are in accordance with Reverter et al. (2000) that all estimates of genetic parameter have high standard errors caused by the limited data.

The heritability of body dimension (BW, CC, BL and $\mathrm{WH}$ ) was better than the heritability of WW, YW and BWG. According to Davis and Simmen (2006), differences in heritability could be due to sampling effects. However, body 
Table 1. Heritability (diagonal) and Genetic Correlations (above diagonal)

\begin{tabular}{lccccccc}
\hline & WW & YW & BWG & BW & CC & BL & WH \\
\hline WW & $0.09 \pm 0.15$ & 0.314 & 0.182 & -0.154 & -0.134 & -0.093 & -0.062 \\
YW & & $0.27 \pm 0.13$ & 0.809 & -0.103 & -0.079 & -0.135 & -0.084 \\
BWG & & & $0.47 \pm 0.15$ & -0.169 & -0.062 & -0.158 & -0.040 \\
BW & & & & $0.07 \pm 0.19$ & 0.510 & 0.609 & 0.503 \\
CC & & & & & $0.50 \pm 0.19$ & 0.435 & 0.844 \\
BL & & & & & & $0.34 \pm 0.28$ & 0.476 \\
WH & & & & & & & $0.60 \pm 0.21$ \\
\hline
\end{tabular}

WW= Weaning Weight; YW= Yearling Weight; BWG= Body Weight Gain; BW= Body Weight; $\mathrm{CC}=$ Chest Circumference; $\mathrm{BL}=$ Body Length; $\mathrm{WH}=$ Wither Height

dimension, such as $\mathrm{CC}, \mathrm{BL}$ and $\mathrm{WH}$ did not have a positive correlation to other traits. Thus the traits considered to be selected for is weaning weight, yearling weight and body weight gain. Due to the last two traits (yearling weight and body weight gain) are time consume for doing selection we considered that weaning weight is the trait to be selected. Selection performed on the traits which is closely positive correlated will provide high response to selection whereas no strong correlation will produce a low response to selection (Davis and Simmen, 2006; Kealey et al., 2006). By knowing the magnitude and the sign of genetic correlation of trait that will be selected, it can be expected to improve of the traits in population for the next generation.

Genetic improving of weaning weight, yearling weight and body weight gain (Figure 1) which calculated based on the breeding value estimation, has a similar pattern of decline. Such a trend line indicates that genetically there is no increase in weaning weight, yearling weight and body weight gain due to selection for 28 years. Similarly, genetic improving of body dimension (Figure 2) has a pattern of decline every year. Positive breeding values were achieved in the first year (1994), second year (1995) and third year (1996), the following year was negative. For body weight, genetic improving has declined in the second year (1995), while for genetic improving of body length, positive breeding value was in the fourth year (1997), the rest have a negative breeding value. Sasaki et al. (2006) obtained a genetic improving for 10 years after the selection of the population Japanese Black (Wagyu) on carcass traits. The genetic improving indicates that progeny test on the on-farm effectively improve the carcass traits of Wagyu population.

Decline in genetic improving for all traits were due to the selection made by P3Bali less precise. Inappropriate selection was partly due to mismanagement in the performance tests that are not in accordance with the provisions of performance test by Beef Improvement Federation (Sukmasari et al., 2002). Somethings were not appropriate as follows (1) the age of cattle tested had an average of 1.5 to 2.5 years, while the conditions should be post-weaning, (2) the participants of performance testing was only males, performance testing should be performed on male and female cattle.

The participants of performance testing from year to year were few and varied. This policy was taken after on 1988 outbreak of Jembrana disease that caused the death of cattle in the test station (Pulukan). To reduce the risk, the participants of performance test were decreased to be 40 heads in the following year. Simulation by Kahi and Hirooka (2005) used 500 males of Japanese Black (Wagyu) for participants of performance test.

Implementation of performance tests conducted only at test station level but not at the level of on farm, as well as progeny test. Sasaki et al. (2006) stated that progeny test performed on the Wagyu population conducted at the level of on-farm and at the level of test stations. In this case genetic improvement is a reflection of the level of on-farm and test station. According to Kahi dan Hirooka (2005) genetic improvement can be done by increasing the intensity of selection. They selected for qualified female to become a parent for bull only after the male offspring passed performance testing.

Breeding value estimation in this study was 


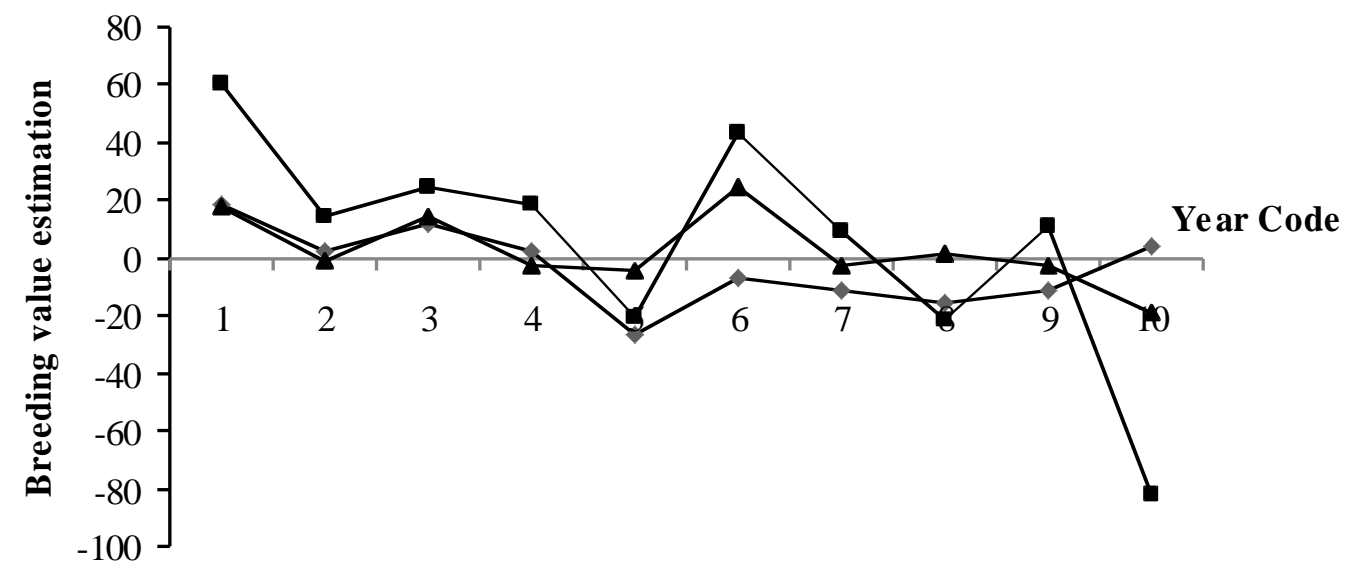

Figure 1. Genetic Improvement of Weaning Weight (WW), Yearling Weight (YW) and Body Weight Gain (BWG). The Symbols Represent Yearling Weight (ם), Body Weight Gain (4) and Weaning Weight $(\bullet)$

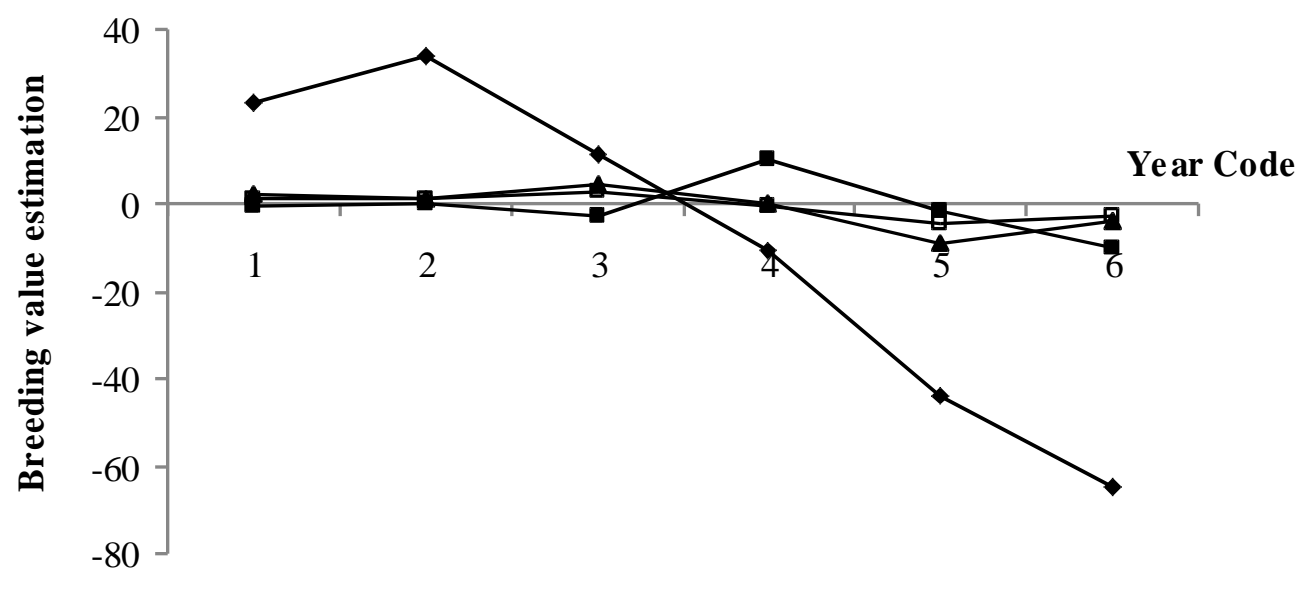

Figure 2. Genetic Improvement of Body Dimension (BW=Body Weight, $\mathrm{CC}=$ Chest Circumference, $\mathrm{BL}=$ Body Length, $\mathrm{WH}=$ Withers Height) Measured at 24 Month Old. The Symbols Represent Body Weight ( ), Body Length ( $\square$ ), Chest Circumference ( $\bullet$ ) and Withers Height ( $\square$ )

breeding value of each individual whether progeny, dam or sire. The higher breeding value of sire the more superiority of the sire, because sires with high breeding value will have offspring with a higher relative advantage as well. Therefore, breeding values can be used as one selection criteria to select for males who are relatively more superior to be utilized his cement widely as possible in the project area and elsewhere.

\section{CONCLUSION}

Based on animal models, the heritability of weaning weight and body weight at 24 month old were low; yearling weight was medium and other characters were considered high. Genetic improving of all the traits had a different pattern in response to selection but they did not show any genetic improvement due to selection. 


\section{REFERENCES}

Bamualim, A. and R.B. Wirdahayati. 2002. Nutrition and Management Strategies to Improve Bali Cattle Productivity in Nusa Tenggara. In: Working Papers: Bali Cattle Workshop. Bali, 4-7 February 2002. P 22-33

Blair, H.T. and E.J. Pollak. 1984. Estimation of genetic trend in a selected population with and without the use of a control population. J. Anim. Sci. 58:878-886

Davis, M.E. and R.C.M. Simmen. 2006. Genetic parameter estimates for serum insulin-like growth factor I concentrations, and body weight and weight gains in Angus beef cattle divergently selected for serum insulin-like growth factor I concentration. J. Anim. Sci. 84: 2299-2308.

Graser, H. 2002. Strategies to improve Bali cattle in eastern Indonesia: implementing pedigree system. In: Working Papers: Bali Cattle Workshop. Bali, 4-7 February 2002. P. 56-64

Groeneveld, E. 1998. VCE4 Programme, User's Guide and Manual Version 1.1. Institut furr Tierzuch und Tierverhalten, FAL, Mariensee.

Jan, R. 2000. Penampilan Sapi Bali di Wilayah Proyek Pembibitan dan Pengembangan Sapi Bali di Daerah Tingkat I Bali. Tesis Program Pascasarjana Universitas Gadjah Mada, Yogyakarta.

Kahi, A.K and H. Hirooka. 2005. Genetic and economic evaluation of Japanese Black (Wagyu) cattle breeding schemes. J. Anim. Sci. 83: 2021-2032

Kaps, M., W.O. Herring and W.R. Lamberson. 2000. Genetic and environmental parameter for traits derived from the Brody growth curve and their relationships with weaning weight in Angus cattle. J. Anim. Sci. 78: 1436-1442

Kealey, C.G., M.D. MacNeil, M.W. Tess, T.W. Geary and R.A. Bellows. 2006. Genetic parameter estimates for scrotal circumference and semen characteristics of Line 1 Hereford bulls. J. Anim. Sci. 84: 283-290

MacNeil, M.D., J.J. Urick and G. Decoudu. 2000. Characteristics of Line 1 Hereford females resulting from selection by independent culling levels for below-average birth weight and high yearling weight or by mass selection for high yearling weight. J. Anim. Sci. 78: 2292-2298.

Mastika, I.M. 2002. Feeding Strategies to Improve the Production Performance and Meat Quality of Bali Cattle (Bos sondaicus). In: Working Papers: Bali Cattle Workshop. Bali, 4-7 February 2002. P. 11-17

Oka, L. 2002. Performance of Bali Heifers and Calves prior to Weaning in Feedlot System. In: Working Papers: Bali Cattle Workshop. Bali, 4-7 February 2002. P. 18-21

Reverter, A., D.J. Johnston, H.U. Graser, M.L. Wolcott and W.H. Upton. 2000. Genetic analyses of live-animal ultrasound and abattoir carcass traits in Australian Angus and Hereford cattle. J. Anim. Sci. 78: 1786-1795

Sasaki, Y., T. Miyake, C. Gaillard, T. Oguni, M. Matsumoto, M. Ito, T. Kurahara, Y. Sasae, K. Fujinaka, S. Ohtagaki and T. Dougo. 2006. Comparison of genetic gains per year for carcass traits among breeding programs in the Japnese Brown and the Japanese Black cattle. J. Anim. Sci. 84: 317-323

Sorensen, D.A and B.W. Kennedy. 1984. Estimation of response to selection using least-squares and mixed model methodology. J. Anim. Sci. 58:1097-1106

Sukmasari, A.H., R.R Noor, H. Martojo and C. Talib. 2002. Pendugaan Nilai Pemuliaan dan Kecenderungan Genetika Bobot Badan Sapi Bali di Proyek Pembibitan dan Pengembangan Sapi Bali. Hayati, 9 (4): 109113

Toelihere, M.R. 2002. Increasing the Success Rate and Adoption of Artificial Insemination for Genetic Improvement of Bali Cattle. In: Working Papers: Bali Cattle Workshop. Bali, 4-7 February 2002. P. 65-73 